\title{
A new hypertonic saline assay for analgesic screening in mice: effects of animal strain, sex, and diurnal phase
}

\section{Nouveau test avec solution saline hypertonique pour l'évaluation analgésique chez la souris : effets de la souche animale, du sexe, et de la phase diurne}

\author{
Yahya I. Asiri, PhD • Desmond H. Fung, MSc (i) - Timothy Fung, PhD - Alasdair M. Barr, PhD (i) • \\ Ernest Puil, PhD • Stephan K. W. Schwarz, MD, PhD, FRCPC • Bernard A. MacLeod, MD, FRCPC
}

Received: 11 August 2020/Revised: 27 October 2020/ Accepted: 29 October 2020/Published online: 18 February 2021

(C) Canadian Anesthesiologists' Society 2021

\begin{abstract}
Purpose There exists a pressing need for the identification of novel analgesics. We recently reported on a new preclinical assay for rapid analgesic screening based on intraplantar (i.pl.) injection of 10\% hypertonic saline (HS)
\end{abstract}

\section{Y. I. Asiri, $\mathrm{PhD}$}

Department of Pharmacology and Toxicology, College of

Pharmacy, King Khalid University, Abha, Saudi Arabia

D. H. Fung, MSc - T. Fung, PhD - E. Puil, PhD .

B. A. MacLeod, MD, FRCPC

Department of Anesthesiology, Pharmacology \& Therapeutics, Hugill Anesthesia Research Centre, The University of British Columbia, Medical Sciences Block C, 2176 Health Sciences

Mall, Vancouver, BC V6T 1Z3, Canada

\section{A. M. Barr, $\mathrm{PhD}$ \\ Department of Anesthesiology, Pharmacology \& Therapeutics, Hugill Anesthesia Research Centre, The University of British Columbia, Medical Sciences Block C, 2176 Health Sciences Mall, Vancouver, BC V6T 1Z3, Canada \\ BC Children's Hospital Research Institute, Vancouver, BC, Canada \\ S. K. W. Schwarz, MD, PhD, FRCPC ( $ه)$ Department of Anesthesiology, Pharmacology \& Therapeutics, Hugill Anesthesia Research Centre, The University of British Columbia, Medical Sciences Block C, 2176 Health Sciences Mall, Vancouver, BC V6T 1Z3, Canada \\ e-mail: stephan.schwarz@ubc.ca}

Department of Anesthesia, St. Paul's Hospital/Providence Health Care, Vancouver, BC, Canada in female outbred (CD-1) mice. Herein, we characterized the HS assay's performance in inbred (C57BL/6) mice, sensitivity to sex differences, and effects of diurnal rhythm phase.

Methods In randomized, controlled, blinded in vivo animal experiments, we studied nociceptive responses induced by i.pl. HS in C57BL/6 (vs CD-1) mice of both sexes $(n=240)$ and determined diurnal rhythm phase effects in female animals. We established the HS assay's sensitivity to morphine by constructing dose-response curves and calculating half-maximal inhibitory doses $\left(I D_{50} s\right)$.

Results The injection of i.pl. HS produced nociceptive (licking and biting) responses in all C57BL/6 mice tested. In both C57BL/6 and CD-1 mice, the mean $195 \%$ confidence interval [CI]) response magnitudes were greater in females vs males (C57BL/6: $87 \mathrm{sec}$ [64 to $110] \mathrm{vs} 45 \mathrm{sec}$ [29 to 61]; difference in means, $42 \mathrm{sec}$; $95 \%$ CI, 17 to 68; $P<0.001 ; n=10 /$ group; $C D-1: 110$ sec [95 to 126] vs $53 \mathrm{sec}$ [32 to 74]; difference in means, $57 \mathrm{sec}$; 95\% CI, 34 to 79; $P<0.001 ; n=10 /$ group). The mean (95\% CI) nociceptive responses were greater at 24:00 hr than at 12:00 hr in C57BL/6 mice (64 sec [40 to 88] vs 37 sec [24 to 51]; difference in means, 27 sec; $95 \%$ CI, 7 to 47; $P=0.007 ; n=10 /$ group $)$, but not in $C D-1$ mice $(P=$ 0.97). Intravenous morphine dose-dependently attenuated nociceptive responses of both $C 57 B L / 6$ and $C D-1$ mice $\left(I D_{50}, 0.6\right.$ and $2.5 \mathrm{mg} \cdot \mathrm{kg}^{-1}$, respectively; $\left.P=0.41\right)$.

Conclusion These findings in inbred and outbred mice solidify the utility of the HS assay as an effective, rapid, robust, and versatile preclinical tool for analgesic screening. 


\section{Résumé}

Objectif Il existe un besoin impérieux d'identification de nouveaux analgésiques. Nous avons récemment publié les conclusions d'un nouveau test préclinique portant sur le dépistage analgésique rapide basé sur l'injection intraplantaire (i.pl.) d'une solution saline hypertonique à $10 \%(H S)$ chez des souris femelles croisées (CD-1). Dans notre présente étude, nous avons caractérisé la performance du test de $H S$ chez des souris consanguines (C57BL/6), la sensibilité aux différences de sexe, et les effets des phases de rythme diurne.

Méthode Dans le cadre d'expériences animales in vivo en aveugle randomisées contrôlées, nous avons étudié les réponses nociceptives induites par une i.pl. de HS chez des souris C57BL/6 (vs CD-1) des deux sexes $(n=240)$ et déterminé les effets des phases du rythme diurne chez les animaux femelles. Nous avons établi la sensibilité du test HS à la morphine en construisant des courbes de doseréponse et en calculant des doses inhibitrices semimaximales $\left(D I_{50}\right)$.

Résultats L'injection i.pl. de HS a produit des réponses nociceptives (léchage et morsure) chez toutes les souris C57BL/6 testées. Chez les souris C57BL/6 et CD-1, les magnitudes de réponse moyenne [intervalle de confiance (IC) $95 \%$ ] étaient plus élevées chez les femelles que chez les mâles (C57BL/6 : 87 [64 à 110] vs 45 [29 à 61] sec; différence de moyennes, 42 sec; IC $95 \%, 17$ à $68 ; P<$ 0,001; $n=10 /$ groupe; CD-1: 110 [95 à 126] vs 53 [32 à 74] sec; différence de moyennes, 57 sec; IC $95 \%, 34$ à 79; $P<0,001 ; n=10$ (groupe). Les réponses nociceptives moyennes [IC $95 \%$ ] étaient plus importantes à minuit (24 h) qu'à midi (12 h) chez les souris C57BL/6 (64 [40 à 88] sec vs 37 [24 à 51 ] sec; différence de moyennes, 27 sec; IC $95 \%, 7$ à 47; $P=0,007 ; n=10 /$ groupe), mais pas chez les souris $C D-1 \quad(P=0,97)$. La morphine intraveineuse a atténué de façon dose-dépendante les réponses nociceptives chez les souris C57BL/6 et CD-1 (DI $I_{50}, 0,6$ et $2,5 \mathrm{mg} \cdot \mathrm{kg}^{-1}$, respectivement; $P=0,41$ ).

Conclusion Ces résultats chez les souris croisées et consanguines appuient l'utilité du test de HS comme un outil préclinique efficace, rapide, robuste et polyvalent pour le dépistage analgésique.

Keywords Pain measurement/drug effects - analgesics · drug screening $\cdot$ analgesics $\cdot$ disease models/animals . mice $\cdot$ drug evaluation $\cdot$ preclinical

There continues to be a pressing need for the identification of novel non-opioid analgesics, evidenced by the ongoing opioid crisis and efficacy constraints combined with the adverse event profile of currently available agents. ${ }^{1-7}$ The realization of this goal hinges in part upon the availability of reliable in vivo analgesic screening assays, which are among the most important features of preclinical pain research. ${ }^{8}$ The success of a preclinical nociceptive assay requires consistency in the magnitude of control or pretreatment responses, the ability to detect clinically used analgesics, and reproducibility within species. ${ }^{9}$ We recently reported on the development of a new nociceptive assay in mice based on the intraplantar (i.pl.) injection of $10 \%$ hypertonic saline (HS), ${ }^{10,11}$ previously shown to produce nociceptive stimulation in a study of transient receptor potential vanilloid 4 (TRPV4) channels. $^{12}$ The HS assay evokes nociceptive responses that are reproducible in the same animal regardless of repetitive testing and rapidly detects antinociceptive activities of a range of established centrally and peripherally acting analgesics belonging to the principal classes. ${ }^{11}$ This allows each animal to serve as its own control, thereby reducing response variability and the number of animals needed. At the same time, in contrast to formalinbased assays, the HS assay produces no discernible tissue damage and hence improves animal welfare. ${ }^{10}$ Collectively, these attributes speak to the principles of the 3Rs (Replacement, Reduction, and Refinement) in the development of more humane animal research. ${ }^{13}$

Nevertheless, the HS assay was developed exclusively using mice from an outbred stock, CD-1. To show assay versatility, robustness, and broad utility, it is imperative to investigate its performance using mice from a common inbred strain. Inbred mice are generally preferred over outbred mice in biomedical research. One reason is that outbred mice possess greater genetic variability due to cross-breeding. In contrast, inbred mice are isogenic to one another and therefore possess less phenotypic variability. Thus, fewer animals are required to maintain similar statistical power (Reduction), and response variability may be reduced (Refinement). ${ }^{14}$ Inbred mice are also preferred because of their central role in creating transgenic knockout mice. Typically, embryonic stem cells from the inbred 129 strain are microinjected into embryo cells of the inbred C57BL/6 strain. ${ }^{15}$ Since most transgenic knockout mice originate from an inbred genetic background ${ }^{16}$ and have been widely employed in preclinical pain research, ${ }^{17}$ testing the HS assay with C57BL/6 mice is a priority.

Differences in nociceptive responses and analgesic sensitivity within rodent species have been well documented in many pain assays. ${ }^{18}$ In one study involving 11 inbred mice strains, large variations in baseline nociceptive sensitivity were found with C57BL/6 in a variety of nociceptive, thermal, and chemical pain assays. ${ }^{19}$ With regard to analgesic sensitivity, the C57BL/6 strain is known to be resistant to many analgesics compared with other inbred mouse strains. ${ }^{16,20}$ These differences likely arise from genetic influences ${ }^{20}$ and the nature of noxious 
stimuli. To complicate matters, some assays also display sexspecific differences within strains. ${ }^{21}$ In thermal pain assays, C57BL/6 males have lower baseline nociceptive sensitivities compared with females ${ }^{22}$ whereas no sex differences have been observed with outbred CD-1 mice. ${ }^{23}$ Differences also exist in chemical nociceptive assays. For example, both sexes of C57BL/6 mice exhibit larger nociceptive responses than CD-1 mice in phase I and II of the standard formalin foot test. $^{21}$ Because the HS assay was recently developed, response variability due to strain and sex effects have not yet been thoroughly investigated.

The goal of the present study was to determine the nociceptive responses of male and female C57BL/6 vs CD1 mice to i.pl. injection of the nociceptive stimulus (HS) using $0.9 \%$ normal saline (NS) as a control. ${ }^{10}$ We further sought to investigate the effects of sex and diurnal rhythm phase on nociceptive responses and assess the ability of the HS assay to detect the antinociceptive activity of the "gold standard" opioid analgesic, morphine, in C57BL/6 mice. Our principal hypothesis was that the HS assay would evoke morphine-sensitive nocifensive licking and biting behaviour in inbred C57BL/6 mice.

\section{Methods}

We conducted a randomized, controlled, blinded in vivo laboratory animal study. The experimental protocol and procedures were approved by The University of British Columbia Animal Care Committee (Vancouver, BC, Canada) and conducted in accordance with the guidelines of the Canadian Council on Animal Care. Animals were used once and euthanized immediately at the end of testing using isoflurane followed by $\mathrm{CO}_{2}$. We followed the Animal Research Reporting In Vivo Experiments 2.0 (ARRIVE 2.0) guidelines ${ }^{24}$ for the reporting of this study.

\section{Animals}

Adult male and female CD-1 (25-30 g) and C57BL/6 (20-25 g) mice (total $n=240$; Charles River Laboratories, Senneville, QC, Canada) were group-housed (five per cage) at $24^{\circ} \mathrm{C}$ and $45-55 \%$ relative humidity under a 12 -hr lightdark cycle where lights are turned on at 07:00 hr. Animals were given free access to laboratory food and water. Experiments were performed between 09:00 and 17:00 hr, with the exception of those performed at $24: 00 \mathrm{hr}$ (see below).

\section{Drugs and chemicals}

Sodium chloride $(\mathrm{NaCl}$; BDH Chemicals, Toronto, ON, Canada) was dissolved in distilled water to produce saline at different concentrations. $\mathrm{NaCl} 0.9 \%$ (normal saline [NS]) was employed as the negative control throughout the study. Morphine sulfate (Toronto Research Chemicals, Toronto, ON, Canada) was dissolved in NS.

Hypertonic saline analgesic assay

Animals were randomly assigned to control and treatment groups using an internet-based true random number service. ${ }^{25}$ Mice were habituated for two hours in a quiet and temperature-controlled $\left(23^{\circ} \mathrm{C}\right)$ room. Individual mice were then placed in an opaque Plexiglas tube (height, 19 $\mathrm{cm}$; diameter, $9 \mathrm{~cm}$; Associated Plastics and Supply, Vancouver, B.C., Canada). Animals received injections into the middle of the right hind paw with $10 \mu \mathrm{L}$ of either HS or NS $(0.3-\mathrm{mL}$ disposable insulin syringes with $29 \mathrm{G}$ needle; BD, Mississauga, ON, Canada) by an experimenter blinded to group assignment. Mice were immediately placed back into their respective Plexiglas tube and nociceptive responses were recorded for $30 \mathrm{~min}$ using a video camera with night vision capability (Lorex by FLIR, ON, Canada) situated below the clear glass bottom of the observation chamber. The primary outcome was the time animals spent exhibiting nociceptive responses, defined as licking and biting of the injected hind paw, and assessed post hoc in five-minute bins by a separate blinded investigator from the video recordings. Other behavioural responses such as flinching were not considered for the primary endpoint.

Assessment of diurnal rhythm phase effects

Female C57BL/6 and CD-1 mice were randomly allocated to two groups to be tested separately at 12:00 and 24:00 hr, respectively. These time points represent the peaks of rest and activity and are known to influence animal responses to nociceptive stimuli. ${ }^{26,27}$ After the habituation period, mice received an injection of HS or NS into the surface of the right hind paw and were video recorded for five minutes. For animals tested at 24:00 $\mathrm{hr}$, the entire experiment was performed in a dark room; red light was used briefly when administering solutions.

Assessment of sensitivity to the antinociceptive activity of morphine

Female C57BL/6 and CD-1 mice were randomly allocated to receive an intravenous injection of morphine into the tail vein $\left(30 \mu \mathrm{L} ; 0,0.6,2,6\right.$, and $20 \mathrm{mg} \cdot \mathrm{kg}^{-1}$; each animal received only one dose). After five minutes, $10 \mu \mathrm{L}$ of HS were injected into the surface of the right hind paw (i.pl.) as described above and nociceptive responses over the following five minutes were recorded. We used the 
duration of time animals spent licking and biting the injected paw to establish dose-response relationships to assess the HS assay's sensitivity to the antinociceptive activity of morphine in the inbred $v s$ outbred animal strains.

\section{Statistical analysis}

Group responses are plotted with individual data points where feasible and reported as means (95\% confidence intervals [CIs]); effect sizes are reported as differences in means with their $95 \%$ CIs. The amount of time mice spent licking and biting the affected paw during the first five minutes period after i.pl. injection was used for the primary analysis. Two-way analysis of variance (ANOVA) (factors: saline concentration $\times$ sex) followed by the Tukey multiple comparisons test was utilized to determine the effect of sex and saline concentration. To determine the effects of strain and sex on nociceptive responses in C57BL/6 vs CD-1 mice, we used two-way ANOVA (factors: stock/strain $\mathrm{x}$ sex) followed by the Tukey multiple comparisons test. To determine the effects of diurnal rhythm phase and HS in female C57BL/6 and CD-1 mice, we employed two-way ANOVA (factors: time of measurement $\times$ saline concentration) followed by the Sidak multiple comparisons test.

For assessment of the antinociceptive activity of morphine, we constructed dose-response curves using non-linear regression. Specifically, we first normalized dose-dependent nociceptive responses to the mean of control (NS) responses and then fitted the data to a fourparameter (variable slope) logistic equation (log[inhibitor] $v s$ response):

$\mathrm{Y}=$ Bottom $+[$ Top - Bottom $] /\left[1+10^{([\log [\mathrm{D} 50-\mathrm{X}] * \text { Hill slope })}\right]$,

where $\mathrm{Y}$ is the response, Top and Bottom are the minimum and maximum nociceptive responses (plateaus), $\mathrm{ID}_{50}$ is the dose that produces $50 \%$ of the maximal inhibition (i.e., a response half-way between Top and Bottom), $\mathrm{X}$ is the dose, and Hill slope is the slope factor (i.e., the steepness of the curve). We calculated estimated $\mathrm{ID}_{50} \mathrm{~s}$ with their $95 \%$ CIs from the respective curves and used the extra sum of squares $F$ test for statistical comparison.

Individual target sample sizes for each group were $n=$ 10, which was consistent with and adapted from our previous studies. ${ }^{10,11}$ Based on previously observed mean durations of nocifensive licking and biting behaviour in female CD-1 mice due to HS and NS of $96 \mathrm{sec}$ (95\% CI, 76 to 116$)$ and $10 \mathrm{sec}(95 \% \mathrm{CI},-1$ to 21$) \mathrm{sec}$, respectively, ${ }^{10}$ and assuming a common standard deviation of 22 , a sample size of ten animals per group would yield $99 \%$ power to detect a 45 -sec difference between HS and NS and $80 \%$ power to detect a $30-\sec$ difference $(\alpha=5 \%)$. For the morphine dose-response experiments, we studied a sample size of convenience of $n=8$ per dose (total, $n=80$ ).

Analyses were carried out using Prism software (GraphPad Software Inc., San Diego, CA, USA). $P<$ 0.05 was set as the criterion for statistical significance.

\section{Results}

Nociceptive responses elicited by intraplantar hypertonic saline and effects of sex

The i.pl. injection of HS induced robust (i.e., in all animals tested) nociceptive (licking and biting) responses in both male and female C57BL/6 mice (Fig. 1). Two-way ANOVA revealed significant sex $\left(F_{[1,36]}=8.7, P=\right.$ $0.005)$, saline concentration $\left(F_{[1,36]}=79.6, P<0.001\right)$, and interaction effects $\left(F_{[1,36]}=11.3, P=0.002\right)$. Female mice exhibited significant increases in the mean $(95 \% \mathrm{CI})$ duration of nociceptive licking and biting responses to HS compared with NS during the first five-minute interval (87 sec [64 to 110] vs $5 \mathrm{sec}$ [1 to 9], respectively; difference in means, $82 \mathrm{sec}$; 95\% CI, 57 to 107; Tukey multiple comparison test, $P<0.001 ; n=10 /$ group) (Fig. 1A). Male mice also exhibited significant increases in mean licking and biting responses to $10 \%$ HS compared with NS during the first five minutes ( $45 \mathrm{sec}$ [ 29 to 61] vs $8 \mathrm{sec}$ [-2 to 18], respectively; difference in means, $37 \mathrm{sec} ; 95 \% \mathrm{CI}, 12$ to 63 ; Tukey multiple comparison test, $P=0.002 ; n=10$ /group) (Fig. 1A). The mean $(95 \%$ CI $)$ magnitude of the nociceptive responses in female mice injected with HS was significantly higher than in male mice during the first five minutes ( $87 \mathrm{sec}$ [64 to 110] vs $45 \mathrm{sec}$ [29 to 61], respectively; difference in means, $42 \mathrm{sec}$; $95 \% \mathrm{CI}, 17$ to 68 ; Tukey multiple comparison test, $P<0.001 ; n=10 /$ group) (Fig. 1A). As shown in Fig. 1B, the licking and biting response in $\mathrm{C} 57 \mathrm{BL} / 6$ mice was at a maximum during the first five-minute period after injection and gradually subsided over $15 \mathrm{~min}$.

Hypertonic saline induced licking and biting nociceptive responses in both sexes of CD-1 mice, confirming our previous observations. ${ }^{10}$ As revealed by two-way ANOVA, there was a significant sex effect $\left(F_{[1,36]}=20.9, P<\right.$ $0.001)$, saline concentration effect $\left(F_{[1,36]}=184.1, P<\right.$ $0.001)$, and interaction between both parameters $\left(F_{[1,36]}=\right.$ 26.5, $P<0.001$ ). HS induced robust (i.e., in all animals tested) mean $(95 \% \mathrm{CI})$ nociceptive responses in female mice compared with NS control (110 sec [95 to 126] vs 1 sec [ -1 to 2], respectively; difference in means, $109 \mathrm{sec}$; 95\% CI, 87 to 132; Tukey multiple comparison test, $P<$ 0.001; $n=10 /$ group) (Fig. 1C). Males exhibited similar 

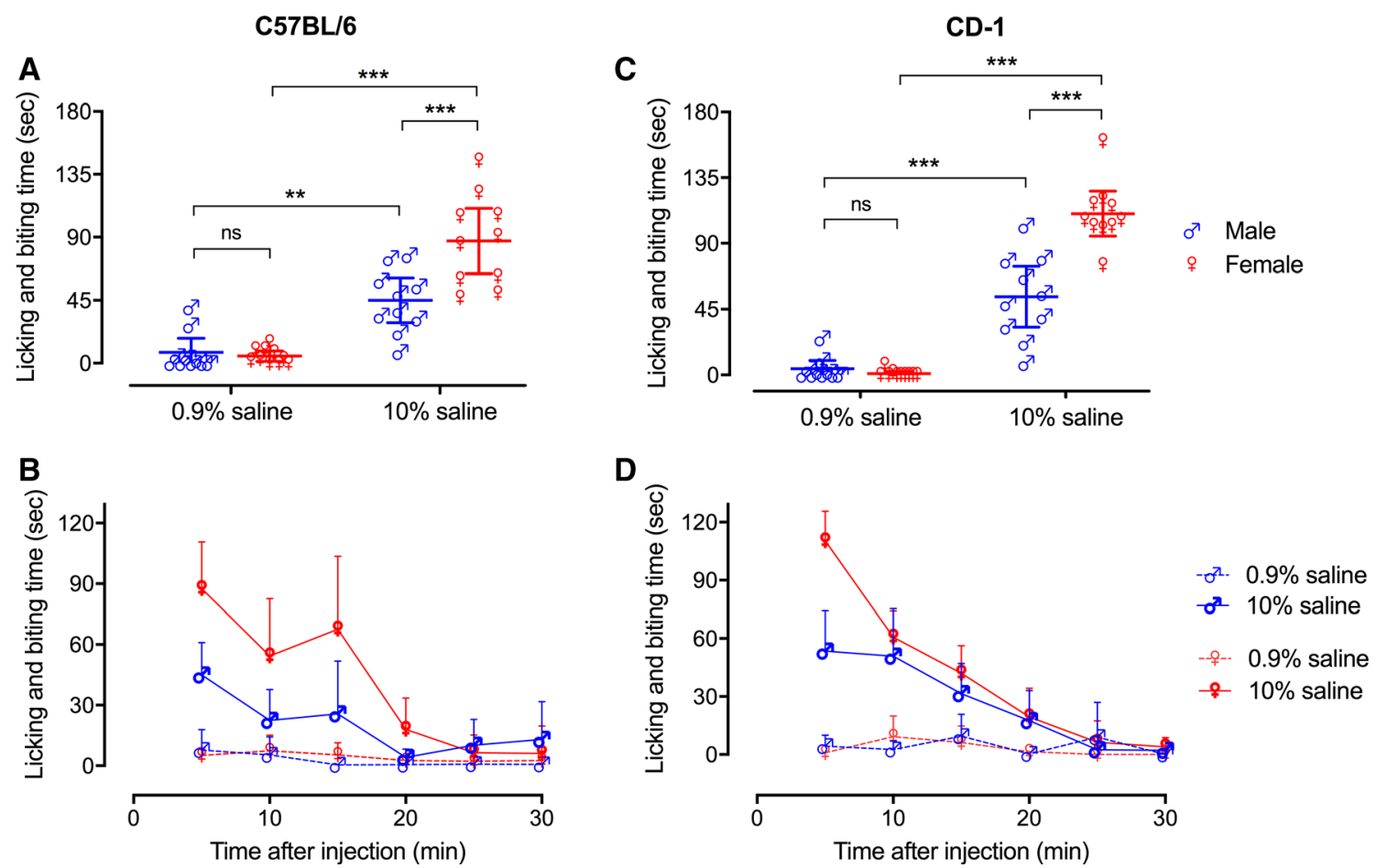

Fig 1 Nociceptive responses of C57BL/6 (inbred) vs CD-1 (outbred) mice induced by intraplantar (i.pl.) $10 \%$ hypertonic saline (HS). A) Comparison of the duration of nocifensive licking and biting behaviour induced by i.pl. HS in male (blue) and female (red) C57BL/6 mice. HS evoked nocifensive licking and biting behaviour in both sexes compared with $0.9 \%$ normal saline (NS) control (twoway analysis of variance followed by the Tukey multiple comparison test: males, $P=0.002\left[{ }^{* *}\right.$ ]; females, $\left.P<0.001[* * *]\right)$. Female mice exhibited greater responses to HS than male mice $(P<0.001[* * *])$. There was no difference between the sexes in their responses to NS control $(P=0.99)$. Each data point represents an individual animal response during the first five-minute interval. Horizontal bars denote mean responses and vertical error bars represent $95 \%$ confidence intervals (CIs). B) Time course of observed licking and biting responses after i.pl. injection of HS vs NS in male $v s$ female C57BL/6 mice. Each point denotes the mean of five-minute interval responses; vertical error bars represent $95 \%$ CIs (same animals as in panel A). C) Comparison of the duration of nocifensive behaviour induced by i.pl. $\mathrm{HS}$ in male (blue) and female (red) CD-1 mice. Consistent with previous observations, ${ }^{10}$ HS evoked nocifensive behaviour in both sexes compared with NS control (both, $P<0.001$ [***]), with females exhibiting greater responses than males $(P<0.001[* * *])$. Similar to C57BL/6 (panel $A$ ), there was no difference between the sexes in their responses to NS $(P=0.98)$. $D)$ Time course of licking and biting responses after i.pl. injection of HS vs NS in male vs female CD-1 mice. Each point denotes the mean of five-minute interval responses; vertical error bars represent $95 \%$ CI (same animals as in panel C). All groups, $n=10$ (total, $n=80$ ). responses with HS vs NS (53 sec [32 to 74] vs $4 \mathrm{sec}$ [ -1 to 10]; difference in means, $49 \mathrm{sec}$; $95 \% \mathrm{CI}, 27$ to 71; Tukey multiple comparison test, $P<0.001 ; n=10 /$ group) (Fig. 1C). The mean $(95 \% \quad \mathrm{CI})$ duration of the nociceptive responses of female $\mathrm{CD}-1$ mice to $\mathrm{HS}$ was twice that of males (110 sec [95 to 126] vs $53 \mathrm{sec}$ [32 to 74], respectively; difference in means, $57 \mathrm{sec}$; $95 \%$ CI, 34 to 79; Tukey multiple comparison test, $P<0.001 ; n=$ 10/group) (Fig. 1C). The nociceptive responses were at a maximum during the first five minutes post-injection and returned to a control level over 10-15 min (Fig. 1D). Similar to the sex differences observed with C57BL/6 mice and consistent with our previous findings, ${ }^{10}$ the mean licking and biting response magnitude in CD-1 mice was larger in females than in males.
When comparing the licking and biting response magnitudes between males and females of C57BL/6 and CD-1 mice, there was a significant sex effect $\left(F_{[1,36]}=\right.$ $34.3, P<0.001)$, no strain effect $\left(F_{[1,36]}=3.5, P=0.07\right)$, and no interaction between strain and $\operatorname{sex}\left(F_{[1,36]}=0.7\right.$, $P=0.39)$. There were no differences in mean $(95 \% \mathrm{CI})$ licking and biting responses of female C57BL/6 vs CD-1 mice following i.pl. HS injection (87 sec [64 to 111] vs 110 sec [95 to 126], respectively; difference in means, $23 \mathrm{sec}$; 95\% CI, 9 to 55; Tukey multiple comparison test, $P=0.24$; $n=10$ (group). We similarly observed no differences in mean $(95 \% \mathrm{CI})$ licking and biting responses of male C57BL/6 vs CD-1 mice following HS injection (45 sec [29 to 61 ] vs $54 \mathrm{sec}$ [33 to 74], respectively; difference in means, 9 sec; $95 \%$ CI, 24 to 41; Tukey multiple comparison test, $P=0.89 ; n=10 /$ group). 
Effects of diurnal rhythm phase on nociceptive responses to intraplantar hypertonic saline

The licking and biting responses of female C57BL/6 mice to HS were sensitive to the time of measurement relative to the diurnal rhythm phase (Fig. 2A). We found a significant time effect $\left(F_{[1,36]}=5.2, P=0.03\right)$, saline concentration effect $\left(F_{[1,36]}=66.1, P<0.001\right)$, and interaction $\left(F_{[1,36]}=\right.$ 4.5, $P=0.04)$ between the two in the nociceptive responses. The mean (95\% CI) licking and biting responses in animals that were tested with $\mathrm{HS}$ at 24:00 hr were significantly higher than those tested at 12:00 hr (64 sec [40 to 88] vs $37 \mathrm{sec}$ [24 to 51], respectively; difference in means, $27 \mathrm{sec}$; 95\% CI, 7 to 47; Sidak multiple comparisons test, $P=0.007 ; n=10$ /group) (Fig. 2A). For CD-1 mice, the results of two-way ANOVA indicated a significant saline concentration effect $\left(F_{[1,36]}=51.8, P<\right.$ $0.001)$ with no time of day effect $\left(F_{[1,36]}=0.1, P=0.80\right)$, and no interaction between treatment and time of day $\left(F_{[1,36]}=0.004, P=0.95\right)$. In other words, in contrast to C57BL/6 mice, there was no effect of diurnal rhythm phase on the nociceptive responses in female CD-1 mice (Sidak multiple comparisons test, $P=0.97 ; n=10 /$ group; Fig. 2B).

Comparative sensitivity to the antinociceptive activity of morphine

Intravenous morphine dose-dependently attenuated the licking and biting responses triggered by i.pl. injection of $\mathrm{HS}$ in both C57BL/6 and CD-1 female mice. Figure 3A shows the dose-response relationship of morphine in C57BL/6 mice with an estimated ID $_{50}$ of $0.6 \mathrm{mg} \cdot \mathrm{kg}^{-1}$ (95\% CI, 0.3 to 1.5 ). Following administration of $\mathrm{HS}$ in female CD-1 mice, morphine similarly produced a dosedependent reduction in licking and biting response duration (Fig. 3B), with an estimated $\mathrm{ID}_{50}$ of $2.5 \mathrm{mg} \cdot \mathrm{kg}^{-1}(95 \% \mathrm{CI}$, 1.5 to 4.2$)$ that was not different from that in $\mathrm{C} 57 \mathrm{BL} / 6$ mice (extra sum of squares $F$ test, $F_{[1,72]}=0.7, P=0.41$ ).

\section{Discussion}

Our study lays the groundwork for future analgesic screening studies as it shows that the HS assay is applicable to inbred (C57BL/6) mice. Indeed, our aim was to test the HS assay using an inbred mouse strain that is extensively used in transgenic pain research. We found that the nociceptive responses of C57BL/6 mice, induced by i.pl. injection of HS, were similar and exhibited minimal phenotypic variability compared with an outbred (CD-1) stock. In both CD-1 and C57BL/6 mice, nociceptive responses occurred as early as five minutes after injection of HS and slowly recovered over approximately $15 \mathrm{~min}$. We also found that the HS assay was sensitive to sex differences and morphine. Similar to CD-1 mice, female C57BL/6 mice were more sensitive to HS than male mice; as well, morphine dose-dependently produced antinociception with comparable potency. To our surprise, the nociceptive responses of female C57BL/6 mice were greater during the dark phase of the diurnal rhythm which was not observed in CD-1 mice. These findings solidify the practicality of the HS assay to induce reliable nocifensive behaviours and detect antinociceptive effects in both outbred and inbred mice.

In both $\mathrm{C} 57 \mathrm{BL} / 6$ and $\mathrm{CD}-1$ mice, the nociceptive responses induced by $\mathrm{HS}$ presented as licking and biting behaviours whose response magnitude depended on sex.

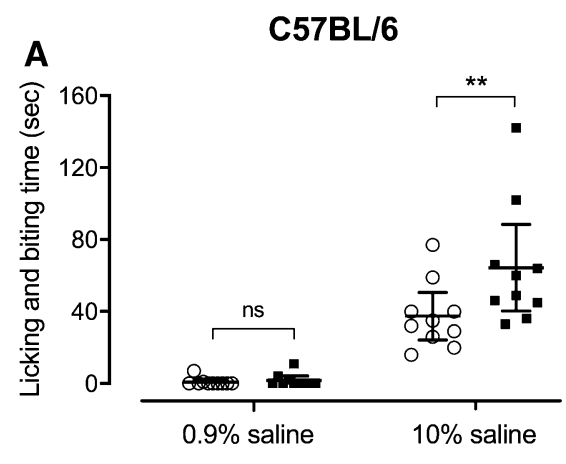

Fig 2 Diurnal rhythm phase effects on nociceptive responses induced by intraplantar $10 \%$ hypertonic saline. A) Nociceptive responses in C57BL/6 (inbred) mice tested at night (24:00) were significantly greater than those of animals tested during the day (12:00; two-way analysis of variance followed by the Sidak multiple comparisons test, $P=0.007[* *])$. There was no difference between the groups in their responses to $0.9 \%$ normal saline control $(P=0.99)$. Each point represents individual animal responses during the first five-minute

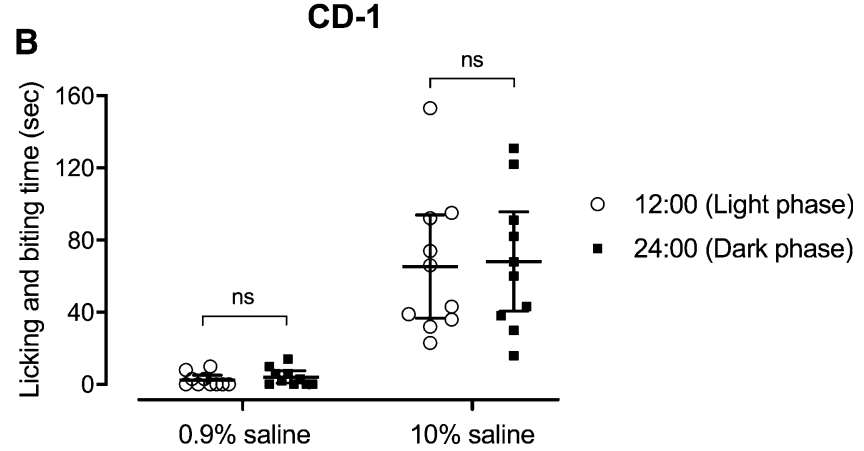

interval. Horizontal summary bars denote means and vertical error bars represent $95 \%$ CIs. B) Nociceptive responses in CD-1 (outbred) mice tested at night (24:00) were not significantly different from those tested during the day $(12: 00 ; P=0.95)$. There was no difference between the groups in their responses to $0.9 \%$ saline control $(P=$ 0.97). All groups, $n=10$ (total, $n=80$ ). 


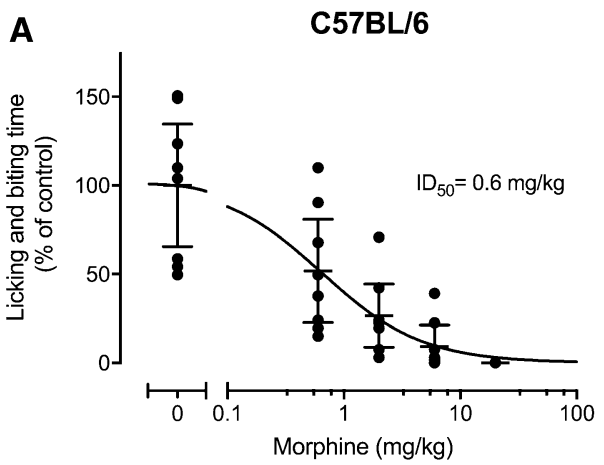

Fig 3 Effects of morphine on nociceptive responses induced by $10 \%$ hypertonic saline. Shown is a dose-dependent attenuation of nocifensive licking and biting responses by intravenous morphine in C57BL/6 (inbred; panel A) mice and CD-1 (outbred; panel B) mice. Each animal received only one dose. Individual responses were normalized to the mean response of the $0.9 \%$ normal saline control group during the first five-minute interval. Horizontal bars and

Female C57BL/6 mice were more sensitive to the HS stimuli than male mice, consistent with both present and previous observations in CD-1 mice. ${ }^{10}$ The ability to detect sex differences in two of the most commonly used laboratory mice highlights the versatility of the HS assay. Several laboratories have used various preclinical pain assays to show the propensity for female rodents, compared with males, to exhibit greater nociceptive responses. ${ }^{28-31}$ The mechanistic basis of the sex differences in preclinical pain assays is not well understood. Nevertheless, sexdependent modulation of nociceptive signals ${ }^{32,33}$ may involve the influence of sex hormones on the activities of neurotransmitter and immune systems. ${ }^{34,35}$ Future studies on the effects of sex hormones, and, in particular, $\gamma$ aminobutyric acid signalling, ${ }^{36}$ may shed light on the mechanism of the sex differences observed with the HS assay. The clinical observation that human female subjects exhibit higher sensory scores compared with males after subcutaneous or intramuscular injection of 5\% HS further corroborates our findings in mice. ${ }^{37}$

Diurnal rhythm phase had differential effects on licking and biting responses induced in the HS assay. We found that inbred C57BL/6 mice exhibited greater licking and biting responses during the dark phase than the light phase. In the formalin foot assay, however, licking and biting responses of C57BL/6 mice during the first ten minutes were similar in both dark and light phases. ${ }^{38}$ Indeed, this may reflect different physiologic mechanisms associated with formalin and hypertonic saline-induced inflammatory pain. It should be noted that while the HS assay did not detect diurnal rhythm phase effects on nociceptive responses of CD-1 mice, other outbred stocks (Deer and CF-1 mice) exhibit higher nociceptive response thresholds during the dark phase. ${ }^{39,40}$ The variable effects of diurnal

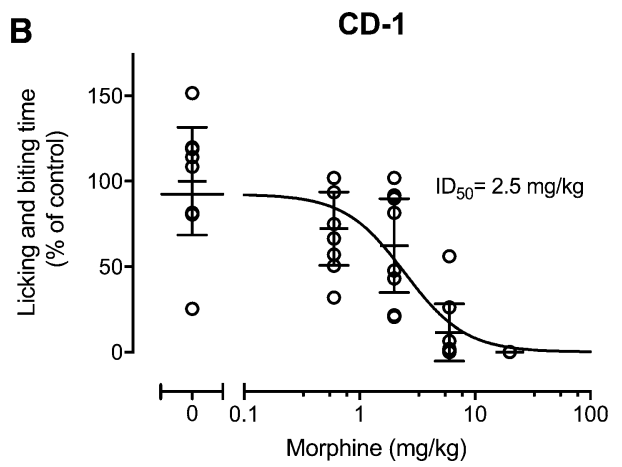

vertical error bars represent means and 95\% confidence intervals, respectively. There was no significant difference between the two (inbred $v s$ outbred) strains in the estimated $\mathrm{ID}_{50}$ of morphine $(P=$ 0.41; details, see body text). Each dose/group, $n=8$ (total, $n=80$ ).

rhythm phase on nociceptive responses induced by HS assay warrant closer investigation.

Systemic morphine decreased licking and biting responses in both female C57BL/6 and CD-1 mice. This is noteworthy as evidence in the literature indicates that C57BL/6 mice are resistant to many analgesics, including morphine. ${ }^{16}$ Further, it has been reported that females require greater morphine doses than males for the same analgesic effect magnitude. ${ }^{22}$ Thus, based on previous studies, one might have expected lower potency estimations for female C57BL/6 mice. In the present studies, we found no significant difference in the estimated potencies between female C57BL/6 and CD- 1 mice. This may be due to differences between the type of nociceptive stimulus used and the primary outcome that was being assessed. Nevertheless, the present findings demonstrate the HS assay's sensitivity to morphine in female C57BL/6 mice, similar to CD-1 mice and with comparable potency.

This study has several strengths. It provides the basis for the extension of the HS assay and its advantagesincluding those on the domains of Reduction and Refinement-for use in C57BL/6 mice, the most popular inbred murine strain for biomedical research involving gene modification and utilized in models of human disorders. The potential benefits for animal welfare, screening efficiency, cost, and drug discovery are immense. The randomized and blinded study design is key to the production of high-quality data and validity. The Table summarizes the attributes of the HS assay and provides a comparative overview of the advantages and disadvantages of existing assays.

The study also has a number of limitations. First, our goal was not to investigate the effects of a wide range of analgesic classes. Future studies that show the HS assay's ability to detect antinociceptive effects in inbred mice of 
Table Overview of common preclinical rodent analgesic screening assays in comparison with the hypertonic saline assay

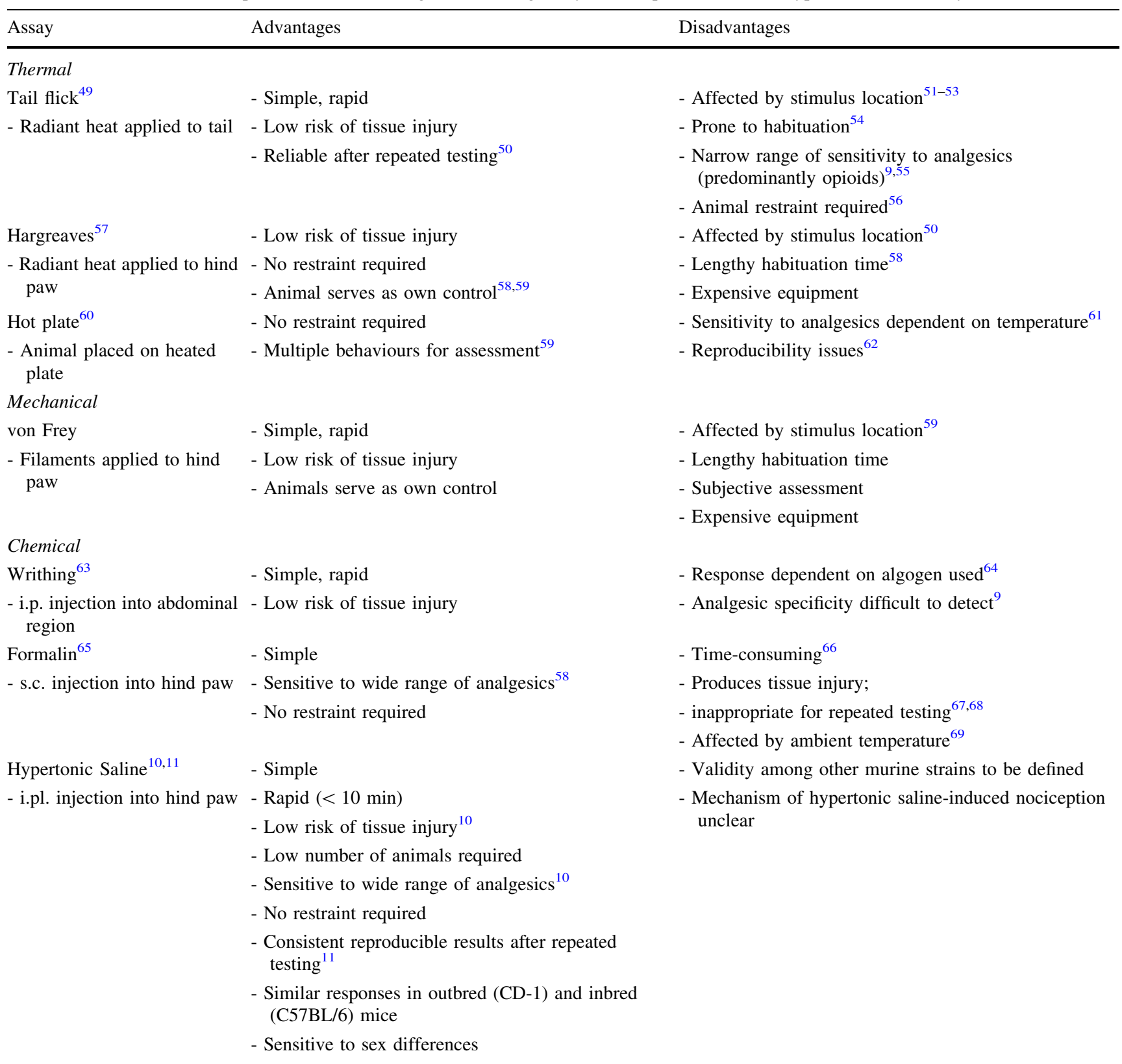

i.p. $=$ intraperitoneal. s.c. $=$ subcutaneous. i.pl. $=$ intraplantar.

such agents as non-steroidal anti-inflammatory drugs or local anesthetics would encourage further adoption of the assay in preclinical analgesic research. Second, only female animals were used in diurnal rhythm phase and morphine studies. An argument can be made that daily tracking of the four-day estrous cycle was necessary to determine hormonal influence on nocifensive behaviours and responses to morphine. Nevertheless, one study found that female mice tested at random were no more variable than males in terms of nociceptive traits. ${ }^{41}$ Another area of future research may be to investigate diurnal rhythm phase and non-opioid analgesic effects in males to supplement our present findings. Third, we assessed only one nocifensive behavioural modality induced by the HS assay. Other behaviours that may be indicators of spontaneously evoked pain include analgesic selfadministration, conditioned place preference, or flinching. ${ }^{42}$ To further support widespread translatability of the HS assay, it may be worthwhile for future studies to assess these behaviours as well. Fourth, we recognize that the phenotypic nociceptive responses to many other murine strains may not be reflected by our results and thus, any 
future research utilizing the HS assay would benefit from method validation for each specific strain. Finally, the precise mechanistic basis of the nociceptive responses due to HS remains unsolved. While it has been long been reported that HS produces acute and transient pain in studies of human muscle and joint pain, ${ }^{43-48}$ room for future mechanistic studies exists to explore the relationship between HS-induced nociception in rodents and acute pain states.

In conclusion, the $10 \% \mathrm{HS}$ analgesic assay produced licking and biting nocifensive behaviours in C57BL/6 mice, detected sex-dependent differences, and was sensitive to the antinociceptive activity of morphine. For preclinical pain assays to be useful, nociceptive responses must be specific, reliable, and sensitive to known analgesics. The present findings extend the utility of the HS assay as an easy, effective, and robust preclinical tool for analgesic screening to inbred mice, thus increasing its generalizability in preclinical research.

Author contributions Yahya I. Asiri was involved in the conception and design of the study, conduct of the experiments, data collection, data analysis, and manuscript preparation; he cowrote the first draft of this paper. Desmond H. Fung was involved in data analysis and manuscript preparation; he co-wrote the first draft of this paper. Timothy Fung helped with the conduct of the experiments, data collection, and manuscript preparation. Alasdair M. Barr, Ernest Puil, Bernard A. MacLeod, and Stephan K. W. Schwarz were involved in the conception and design of the study, data analysis, manuscript preparation, and critical editing for final submission. All authors provided intellectual contributions to this work and approved the final manuscript for submission.

Disclosures Drs Ernest Puil and Bernard MacLeod are minor shareholders of Veritas Pharma (Vancouver, BC, Canada). Dr. Ernest Puil is the Chief Executive Officer of TherExcell Pharma (Vancouver, $\mathrm{BC}$, Canada) which investigates novel compounds as clinical analgesics. Dr. Bernard MacLeod is a member of the Board of Directors of TherExcell Pharma. Dr. Timothy Fung previously was affiliated as a Research Scientist with Cannevert Therapeutics Ltd. (Vancouver, BC, Canada), an organization dedicated to research and development that did not produce any products for sale or generate revenue; he currently is employed by BenchSci (Toronto, ON, Canada). All other authors declare no commercial or non-commercial affiliations except as disclosed under Funding and Other Associations above/below.

Funding statement This study was funded in part by the Dr. Jean Templeton Hugill Endowment for Anesthesia Memorial Fund at The University of British Columbia (Vancouver, BC, Canada). Dr. Schwarz holds the Dr. Jean Templeton Hugill Chair in Anesthesia (Faculty of Medicine, The University of British Columbia, Vancouver, BC, Canada).

Other associations Dr. Stephan K. W. Schwarz at the time of submission and acceptance was a member of the Editorial Board and since January 1, 2021 is the Editor-in-Chief of the Canadian Journal of Anesthesia; he had no involvement in the handling of this manuscript. All other authors declare no other associations.
Editorial responsibility This submission was handled by Dr. Hilary P. Grocott, Former Editor-in-Chief, Canadian Journal of Anesthesia.

\section{References}

1. Woolf CJ. Overcoming obstacles to developing new analgesics. Nat Med 2010; 16: 1241-7.

2. Kissin I. The development of new analgesics over the past 50 years: a lack of real breakthrough drugs. Anesth Analg 2010; 110: 780-9.

3. Burgess $G$, Williams $D$. The discovery and development of analgesics: new mechanisms, new modalities. J Clin Invest 2010; 120: 3753-9.

4. Yaksh TL, Hunt MA, Dos Santos GG. Development of new analgesics: an answer to opioid epidemic. Trends Pharmacol Sci 2018; 39: 1000-2.

5. Belzak L, Halverson J. The opioid crisis in Canada: a national perspective. Health Promot Chronic Dis Prev Can 2018; 38: 224-33.

6. Scholl L, Seth P, Kariisa M, Wilson N, Baldwin G. Drug and opioid-involved overdose deaths - United States, 2013-2017. MMWR Morb Mortal Wkly Rep 2018; 67: 1419-27.

7. Clarke H, Soneji N, Ko DT, Yun L, Wijeysundera DN. Rates and risk factors for prolonged opioid use after major surgery: population based cohort study. BMJ 2014. https://doi.org/10. 1136/bmj.g1251.

8. Mogil JS, Davis KD, Derbyshire SW. The necessity of animal models in pain research. Pain 2010; 151: 12-7.

9. Le Bars D, Gozariu M, Cadden SW. Animal models of nociception. Pharmacol Rev 2001; 53: 597-652.

10. Asiri YI, Fung T, Schwarz SK, et al. An intraplantar hypertonic saline assay in mice for rapid screening of analgesics. Anesth Analg 2018; 127: 548-55.

11. Asiri YI, Fung T, Schwarz SK, et al. Repeated testing with the hypertonic saline assay in mice for screening of analgesic activity. Anesth Analg 2019; 129: 269-75.

12. Alessandri-Haber N, Joseph E, Dina OA, Liedtke W, Levine JD. TRPV4 mediates pain-related behavior induced by mild hypertonic stimuli in the presence of inflammatory mediator. Pain 2005; 118: 70-9.

13. National Centre for the Replacement Refinement \& Reduction of Animals in Research (NC3Rs). The 3Rs. Available from URL: https://www.nc3rs.org.uk/the-3rs (Accessed October 2020).

14. Tuttle AH, Philip VM, Chesler EJ, Mogil JS. Comparing phenotypic variation between inbred and outbred mice. Nat Methods 2018; 15: 994-6.

15. Mogil JS, Grisel JE. Transgenic studies of pain. Pain 1998; 77: 107-28.

16. Lariviere WR, Chesler EJ, Mogil JS. Transgenic studies of pain and analgesia: mutation or background genotype? J Pharmacol Exp Ther 2001; 297: 467-73.

17. Mogil JS, Yu L, Basbaum AI. Pain genes?: natural variation and transgenic mutants. Annu Rev Neurosci 2000; 23: 777-811.

18. Mogil JS. The genetic mediation of individual differences in sensitivity to pain and its inhibition. Proc Natl Acad Sci U S A 1999; 96: 7744-51.

19. Mogil JS, Wilson SG, Bon $K$, et al. Heritability of nociception I: responses of 11 inbred mouse strains on 12 measures of nociception. Pain 1999; 80: 67-82.

20. Wilson SG, Smith SB, Chesler EJ, et al. The heritability of antinociception: common pharmacogenetic mediation of five 
neurochemically distinct analgesics. J Pharmacol Exp Ther 2003; 304: 547-59.

21. Leo S, Straetemans $R$, D'Hooge R, Meert T. Differences in nociceptive behavioral performance between C57BL/6J, 129S6/ SvEv, B6 129 F1 and NMRI mice. Behav Brain Res 2008; 190: 233-42.

22. Kest B, Wilson SG, Mogil JS. Sex differences in supraspinal morphine analgesia are dependent on genotype. J Pharmacol Exp Ther 1999; 289: 1370-5.

23. Kavaliers $M$, Colwell DD. Sex differences in opioid and nonopioid mediated predator-induced analgesia in mice. Brain Res 1991; 568: 173-7.

24. Percie du Sert N, Hurst V, Ahluwalia A, et al. The ARRIVE guidelines 2.0: updated guidelines for reporting animal research. Br J Pharmacol 2020; 177: 3617-24.

25. RANDOM.ORG: Randomness and Integrity Services Ltd. Random Sequence Generator. Available from URL: https:// www.random.org (Accessed October 2020).

26. Castellano C, Puglisi-Allegra S, Renzi P, Oliverio A. Genetic differences in daily rhythms of pain sensitivity in mice. Pharmacol Biochem Behav 1985; 23: 91-2.

27. Turek FW, Joshu C, Kohsaka A, et al. Obesity and metabolic syndrome in circadian Clock mutant mice. Science 2005; 308: 1043-5.

28. Aloisi AM, Albonetti ME, Carli G. Sex differences in the behavioural response to persistent pain in rats. Neurosci Lett 1994; 179: 79-82.

29. Perissin L, Facchin P, Porro CA. Tonic pain response in mice: effects of sex, season and time of day. Life Sci 2003; 72: 897-907.

30. Mogil JS, Chesler EJ, Wilson SG, Juraska JM, Sternberg WF. Sex differences in thermal nociception and morphine antinociception in rodents depend on genotype. Neurosci Biobehav Rev 2000; 24: 375-89.

31. Berkley KJ. Sex differences in pain. Behav Brain Sci 1997; 20: 371-80.

32. Lei J, Jin L, Zhao $Y$, et al. Sex-related differences in descending norepinephrine and serotonin controls of spinal withdrawal reflex during intramuscular saline induced muscle nociception in rats. Exp Neurol 2011; 228: 206-14.

33. Mifflin KA, Benson C, Thorburn KC, Baker GB, Kerr BJl. Manipulation of neurotransmitter levels has differential effects on formalin-evoked nociceptive behavior in male and female mice. J Pain 2016; 17: 483-98.

34. Sorge RE, Totsch SK. Sex differences in pain. J Neurosci Res 2017; 95: 1271-81.

35. Craft RM, Mogil JS, Aloisi AM. Sex differences in pain and analgesia: the role of gonadal hormones. Eur J Pain 2004; 8: 397-411.

36. Frye CA, Duncan JE. Progesterone metabolites, effective at the $\mathrm{GABA}_{\mathrm{A}}$ receptor complex, attenuate pain sensitivity in rats. Brain Res 1994; 643: 194-203.

37. Henderson LA, Gandevia SC, Macefield VG. Gender differences in brain activity evoked by muscle and cutaneous pain: a retrospective study of single-trial fMRI data. Neuroimage 2008; 39: 1867-76.

38. Zhang $\mathrm{J}$, Li H, Teng $\mathrm{H}$, et al. Regulation of peripheral clock to oscillation of substance $\mathrm{P}$ contributes to circadian inflammatory pain. Anesthesiology 2012; 117: 149-60.

39. Kavaliers $M$, Innes $D G$. Sex and day-night differences in opiateinduced responses of insular wild deer mice, Peromyscus maniculatus triangularis. Pharmacol Biochem Behav 1987; 27: 477-82.

40. Kavaliers $M$, Hirst $M$. Daily rhythms of analgesia in mice: effects of age and photoperiod. Brain Res 1983; 279: 387-93.
41. Mogil JS, Chanda ML. The case for the inclusion of female subjects in basic science studies of pain. Pain 2005; 117: 1-5.

42. Mogil JS, Crager SE. What should we be measuring in behavioral studies of chronic pain in animals? Pain 2004; 112: 12-5.

43. Kellgren JH. Referred pains from muscle. Br Med J 1938; 1: 325-7.

44. Steinbrocker O, Isenberg SA, Silver M, Neustadt D, Kuhn P, Schittone $M$. Observations on pain produced by injection of hypertonic saline into muscles and other supportive tissues. J Clin Invest 1953 ; 32: 1045-51.

45. Ashton-Miller JA, McGlashen KM, Herzenberg JE, Stohler CS. Cervical muscle myoelectric response to acute experimental sternocleidomastoid pain. Spine (Phila Pa 1976) 1990; 15: 1006-12.

46. Jensen $K$, Norup $M$. Experimental pain in human temporal muscle induced by hypertonic saline, potassium and acidity. Cephalalgia 1992; 12: 101-6.

47. Arendt-Nielsen L, Graven-Nielsen T, Svarrer H, Svensson P. The influence of low back pain on muscle activity and coordination during gait: a clinical and experimental study. Pain 1996; 64: 231-40.

48. Bennell K, Hodges $P$, Mellor R, Bexander $C$, Souvlis T. The nature of anterior knee pain following injection of hypertonic saline into the infrapatellar fat pad. J Orthop Res 2004; 22: 116-21.

49. D'amour FE, Smith DL. A method for determining loss of pain sensation. J Pharmacol Exp Ther 1941; 72: 74-9.

50. Mogil JS, Wilson SG, Wan Y. Assessing nociception in murine subjects. In: Kruger L, editor. Methods in Pain Research. Boca Raton: CRC Press; 2001. p. 11-39.

51. Yoburn BC, Morales $R$, Kelly DD, Inturrisi CE. Constraints on the tailflick assay: morphine analgesia and tolerance are dependent upon locus of tail stimulation. Life Sci 1984; 34: 1755-62.

52. Ness TJ, Jones SL, Gebhart GF. Contribution of the site of heating to variability in the latency of the rat tail flick reflex. Brain Res 1987; 426: 169-72.

53. Prentice $T W$, Joynes $R L$, Meagher $M W$, Grau $J W$. Impact of shock on pain reactivity: III. The magnitude of hypoalgesia observed depends on test location. Behav Neurosci 1996; 110 : 528-41.

54. Groves $P$, Lee D, Thompson R. Effects of stimulus frequency and intensity on habituation and sensitization in acute spinal cat. Physiol Behav 1969; 4: 383-8.

55. Whiteside GT, Pomonis JD, Kennedy JD. An industry perspective on the role and utility of animal models of pain in drug discovery. Neurosci Lett 2013; 557 Pt A: 65-72.

56. d'Amore A, Chiarotti F, Renzi P. High-intensity nociceptive stimuli minimize behavioral effects induced by restraining stress during the tail-flick test. J Pharmacol Toxicol Methods 1992; 27 : 197-201.

57. Hargreaves $K$, Dubner $R$, Brown $F$, Flores $C$, Joris $J$. A new and sensitive method for measuring thermal nociception in cutaneous hyperalgesia. Pain 1988; 32: 77-88.

58. Barrot $M$. Tests and models of nociception and pain in rodents. Neuroscience 2012; 211: 39-50.

59. Deuis JR, Dvorakova LS, Vetter I. Methods used to evaluate pain behaviors in rodents. Front Mol Neurosci 2017; 10: 284.

60. Woolfe G, MacDonald AD. The evaluation of the analgesic action of pethidine hydrochloride (Demerol). J Pharmacol Exp Ther 1944; 80: 300-7.

61. Taber RI. Predictive value of analgesic assays in mice and rats. Adv Biochem Psychopharmacol 1973; 8: 191-211.

62. Tjølsen A, Hole K. Animal models of analgesia. In: Dickenson A, Besson JM (Eds). The Pharmacology of Pain. The Pharmacology 
of Pain. Handbook of Experimental Pharmacology, vol 130. Berlin: Springer; 1997: 1-20.

63. Siegmund $E$, Cadmus $R, L u G$. A method for evaluating both nonnarcotic and narcotic analgesics. Proc Soc Exp Biol Med 1957; 95: 729-31.

64. Collier HO, Dinneen LC, Johnson CA, Schneider C. The abdominal constriction response and its suppression by analgesic drugs in the mouse. Br J Pharmacol Chemother 1968; 32: 295-310.

65. Hunskaar $S$, Fasmer $O B$, Hole $K$. Formalin test in mice, a useful technique for evaluating mild analgesics. J Neurosci Methods 1985; 14: 69-76.

66. Sawynok J, Liu XJ. The formalin test: characteristics and usefulness of the model. Rev Analg 2003; 7: 145-63.
67. Fu KY, Light AR, Maixner W. Long-lasting inflammation and long-term hyperalgesia after subcutaneous formalin injection into the rat hindpaw. J Pain 2001; 2: 2-11.

68. Salinas-Abarca AB, Avila-Rojas SH, Barragan-Iglesias $P$, Pineda-Farias JB, Granados-Soto $V$. Formalin injection produces long-lasting hypersensitivity with characteristics of neuropathic pain. Eur J Pharmacol 2017; 797: 83-93.

69. Rosland $J H$. The formalin test in mice: the influence of ambient temperature. Pain 1991; 45: 211-6.

Publisher's Note Springer Nature remains neutral with regard to jurisdictional claims in published maps and institutional affiliations. 